\title{
Pesantren Contributors People Voice and Builders Akhlakul Karimah
}

\author{
M. Zainul Umam ${ }^{1}$ \\ \{umamcc1@gmail.com ${ }^{1}$ \} \\ Islamic University of Jakarta, Jakarta Indonesia ${ }^{1}$
}

\begin{abstract}
Boarding is one of the educational institutions that contribute to the existence of the Indonesia as a nation as well as the State of the nation (nation state). The role of the pesantren very vital in shaping communal life harmony society of Indonesia. The presence of religious schools that in fact all its institutions of informal education in General, thus can embrace people from various walks of life. The seminary is the orientation of educational institutions on the construction of the akhlakulkarimah makes it a kind of moral agent/morals for learners which will dive amongst the people. That inspired the author to examine more deeply about what and how the actual role of the pesantren in realizing a society's akhlakul karimah.
\end{abstract}

Keywords: Education, Pesantren, Kiai, Educators, Students, Community Agency, Morality.

\section{Introduction}

Education boarding schools on lately is often denigrated by some in the community, perhaps because public education is more promising in terms of Alumni like to be economists, bisnisman, and so on, even though boarding schools has a very important role in the lives of both individuals and the nation and the State. It is because in addition to boarding schools teach religious studies also forms the character of the students had a good behavior or akhlakul karimah as exemplified by the Prophet. Because in essence Islam is a religion of morals as the words of the Prophet

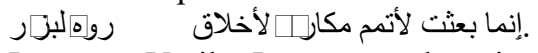

It means: Verily, I am sent only to improve morals (HR Al Bazzar).

Akhlalkulkarimah is a very vital element in the lives of individuals and the life of the nation and the State. Because of the existence of a nation and a country in need of a civilized society and role and cultured. In this case, morals is one of the most important part in shaping the society that high's civilization. And the pesantren education system is the only one who focus themselves on moral development.

From the explanation above, the authors wanted to dissect the contribution of religious schools in its position as medium and forming a generation's akhlakulkarimah. 


\section{Discussion}

Education is the process someone develop the ability to form characters, other attitudes and behaviour in society. Pesantren education system is the totality of interaction of a set of elements of integrated education in cooperation, and complement each other towards the achievement of educational goals that have become goals, together with the the culprit. Boarding schools is a traditional Islamic education institutions to understand and practice the teachings of the Islamic religion (tafaqquh fiddin).

The purpose of education boarding schools is "to create and develop the personality of the Muslims, namely the faithful and pious personality to God Almighty, of benefit to society or to the community served by the road become the subjects or the man the community, with a focus on behavior-good behavior (akhlakulkarimah) as the Prophet Muhammad (follow the sunnah of the Prophet), able to stand on its own, free and fast in the personality, to proselytise or to uphold Islam and the triumph of the people Islam amongst the people (' izzul Islam wal Muslimeen '), and a love of science in order to develop the personality of Indonesia. Ideally the intended personality development is the personality of muhsin, not just Muslims.

The vision is to become a boarding school education institution-based aswaja who has the edge in producing the righteous generation, having an understanding and competence in the fields of Islamic Science and technology, as well as the soul of leadership

As for the mission boarding school education :

a. Organizing a system of education that is conducive towards the establishment of a private lot

b. Develop the education system oriented to the creation of a generation that has understanding and competence in the fields of Islamic Science and technology

c. Form a generation that has the leadership and care about the people

d. Role in Da'wah people and encourage the creation of civil society

e. The boarding community, starting from kiai as founder, teacher and sometime nanny.

Nanny position generally succeeded by the families or relatives of kiai. Teachers boarding schools was a kiai and assisted the ustadz. Kiai as caregivers while the main teachers whereas the ustadz as a teacher helper consists of the senior student or supervisor and caretaker cottages. The position of kiai as caretakers is besides being a teacher was also the deciding level of graduation. The ustadz supervisor who generally from family kiai is the referrer in the teaching and learning activities. As for senior students (mu'allimin) is implementing the daily teaching and learning activities. Santri is a student at boarding school. In general students staying or residing for several years because it comes from out of town. But there are also studen $\neg$ ts from the surrounding communities who just follow the activities of the Koran at the time of the evening. This kind of students is known as students Kalong. Boarding schools accommodating students sons and daughters.

Boarding school administrators in general they are the kiai (nanny/responsible), ustadz, and senior students, who are also alumni, with respect to this role not only do they provide lessons of religion, provide guidance to students, and provide consideration to kiai in the decision also takes care of pesantren in managerial as well as the physical construction of the boarding school.

Curriculum and learning resources, types of pesantren education non formal, studied the religion, on classic books includes the fields of study: Monotheism, Tafsir, Hadith, Fiqh, UsulDefination, Tasawauf, Arabic (Nahwu, nerves, Balagah, and Tajwid), Mantik, and Morals. In addition there are also boarding school education generally various kinds of orders that mu'tabaroh like naqsyabandiyah, syazdaliyah and others. 
The values that underlie the boarding school can be classified into two groups: (1) the values of the religion that has absolute truth, which in this case are Nietzsche, Fiqh and oriented on the life of ukhrawi, and (2) the values of the religion that has the truth of the relative proximity of the empirical and pragmatic to solve various problems of everyday life according to the law of the religion. Both groups of these values has a vertical relationship or hirearchis. The first group of values above the superior value of the second group, and the second value must not conflict with the value of the first group. In this regard kiai as caretakers keep religious values are the first group, ustadz, represented by senior students and students of religious values keeping the second group. This is why kiai as caretakers have absolute power in boarding school.

Pesantren education system using a holistic approach, which means that the nanny looked at that teaching and learning activities is kesatupaduan or melting in the totality of the activities of daily living. To the residents of boarding school, studied at boarding school did not know the timing, when to start and should be done, and what targets to be achieved.

The method of teaching is given in the form: sorogan, halaqoh, bandongan, and memorizing. Sorogan, meaning learning individually where a student dealing with a teacher, there is an interaction between the two know each other. Bandongan does it mean to learn in a group followed by all students.

\section{The role of the pesantren education against the formation of moral}

The moral question here is Islamic or moral are more commonly known as akhlakul karimah as the Foundation of the lives of Muslims.

As educational institutions, pesantren is one of the many education that more emphasis in the fields of morals. It is evidenced by the extensive use of curriculum books style morals. In addition the rules very strict boarding school scored each student to behave in moral terms.

Among the teaching-teaching morals and reproduce scientific knowledge of Sufism, and the end of the period of study is given instruction through devotion and implicitly, both of which are part of forming moral values. Sufism is the educational training to cultivate the heart and spiritual experience as a sign of maturity in the learned. Sufism is the pattern of training that prefer at practice. Therefore, Sufism can be said as the interpretation of the science curriculum has been studied in madrasa diniyyah which in the end is the establishment of good behavior (akhlakul karimah).

Although not structured by default, the system of education in a boarding school can be categorized in some basics of formation morals are: integrity, discipline, social and societal

Integrity, integrity training students in boarding schools is the first thing that is highly emphasized. Through adherence to kiai that acts as the manufacturer of the regulations in the boarding school, students in the law and to comply with these rules. The power of kiai as absolute truth, in the local level, indirectly shape the santri are loyal to what was ordered kiai.

Social Development, community social attitudes of religious schools have been taught well. It is proven by the existence of interaction and communication among the students who applied. Respect for the older and the younger dote. This is the most fundamental statement in the training activities of community in community of students. 


\section{Conclusion}

Education-oriented integrity, discipline and social development is the most important part to make the personality of individuals as one element in civil society (civil society). Islam is the religion of the focus on the third such behaviour. In Islam, all three are part of the teachings on akhlakul karimah (good behavior). Morals in Islam is the most important thing is to be done by all his people. Boarding schools have an important role as agents of delivery and the establishment of morals from one generation to the next (morality agency). And it has been realized by a pesantren since long ago. It is this excess of boarding schools compared to other educational institutions.

\section{References}

[1]. Aljamaly, Fadhil, Muhammad Filsafat Pendidikan Dalam Al Qur'an, disadur Drs. Judi Al Falasany, Bina Ilmu, Surabaya, 1986.

[2]. Boland, B. J. Pergumulan Islam di Indonesia, Grafiti Press, Jakarta, 1985.

[3]. Bronfenbrenner, Uril Two Worlds Of Chilhood, Penguin Education, Australia, 1974

[4]. Departemen, Agama, Nama dan Data Pondok Pesantren Seluruh Indonesia, tahun

$1984 / 1985$

[5]. Dhofier, Zamachsyari, Tradisi Pesantren, LP3ES, Jakarta, 1982.

[6]. Djamari, Nilai-nilai Agama dan Budaya yang Melandasi Interaksi Sosial di Pondok Pesantren Cikadulun Banten, Disertasi doktor Fakultas pasca sarjana IKIP Bandung, 1985.

[7]. Djatmika, Rahmat, Pandangan Islam Tentang Pendidikan Luar Sekolah, dalam : Pembangunan Pendidikan dalam Pandangan Islam, IAIN-Surabaya, 1986.

[8]. Faruki, R. Ismail, Islamisasi Ilmu Pengetahuan, Terjemahan Anas Mahyuddin, Pustaka Bandung, 1984.

[9]. Fattah, Nanang, Landasan Managemen Pendidikan, cet.1, Bandung : PT. Remaja Rosda Karya, 1996.

[10]. Geertz, Clifford, The Javanese Kyai: The Changing Role of a Cultural Broker, New York, vol. 2.

[11]. Hasan, Fuad "Selayang Pandang Tentang Penddikan Islam", dalam pesantren, No.I/Vol. II/1985, P3M, Jakarta, 1985.

[12]. Holt, John Freedom and Beyond, Penguin Books,Australia, 1972.

[13]. Indrawijaya, Ibrahim, Adam MPA, Perilaku organisasi, Sinar Baru, Bandung, 1983.

[14]. Irsyad, Ma'ruf, Sejarah Berdirinya Pondok Pesantren Raudlatul Muta'allimin, Kudus : Perc. Menara Kudus, 2000.

[15]. Langgulung, Hasan Beberapa Pemikiran tentang Pendidikan Islam, Al-Ma'arif, Bandung, 1979.

[16]. Majelis Ulama Indonesia, Amanat Sejarah Umat Islam Indonesia, Keputusan

[17]. Rapat Pengurus Paripurna ke II, Sekretariat MUI, Masjid Istiqlal Jakarta, 1986.

[18]. Marzuki, Metodologi Riset, Yogyakarta : BPFE, UII, 1955.

[19]. Mastuhu, Dinamika Sistem Pendidikan Pesantren, Jakarta : INIS, 1994.

[20]. Nadzir, Mohammad, Metodologi Penelitian, Jakarta : Ghalia Indonesia, 1988.

[21]. Neill, A.S. Summerhill, Penguin Books, Australia, 1972, Suryabrata.

[22]. Nasution, Harun, "Manusia Menurut Konsep Islam", dalam Islam dan pendidikan Nasional, Lembaga penelitian IAIN Jakarta, 1983.

[23]. Nasution, Harun Teologi Islam, Aliran-aliran Sejarah Analisa Perbandingan, UI Press, 1983.

[24]. Prasojo, Soedjoko, dkk, Profil Pesantren, LP3ES, Jakarta, 1973.

[25]. Qutub, Muhammad, Sistem Pendidikan Islam, Terjemahan Salman Harun, Al ma'arif-Bandung, 1984.

[26]. Rahim, Tahrizul, Ahmad dan Pudjosumesdi, Islam dan Peranan Wanita Sebagai $\quad$ Ibu Rumah Tangga dan Tiang negara, Solo : CV. Aneka, 1991. 
[27]. Raharjo, Dewan, M, ED, Pesantren dan Pengembangan Masyarakat, LP3ES Jakarta, 1974.

[28]. Sulaiman, Hasan, Fathiyah (penerjemah), Konsep Pendidikan al-Ghozali, P3M, Jakarta, 1986.

[29]. Sumadi, Metodologi Penelitian, Jakarta, Rajawali Press : 1992.

[30]. Syari'ati, Ali, Tentang Sosiologi Islam, Terjemahan Syaefullah Mahyuddin, Ananda, Yogyakarta, 1982.

[31]. Syihab, M. Quraish, Membumikan Alqur’an, Bandung : Mizan, 1991.

[32]. Wahid, Abdurrahman Bunga Rampai Pesantren, Kumpulan karya tulis, CV Dharma Bakti, Jakarta, $1399 \mathrm{H}$.

[33]. Wahid, Marzuki, Pesantren Masa Depan Wacana Pemberdayaan dan Transformasi Pesantren, Bandung : Pustaka Hidayah, 1999.

[34]. Zuhri, Syaefuddin, KH. Guruku Orang-orang dari Pesantren, Al-Ma'arif, Bandung, 1977. 